\section{Tuk-Utuk Culture and Improvement Madura Community Welfare}

\author{
Syaful Anam, ${ }^{1}$ Nanda Saputra ${ }^{2}$ \\ ${ }^{1}$ STITMA Yogyakarta, Indonesia \\ 2STIT Al-Hilal Sigli, Indonesia \\ Email: syaifulanam@stitmadani.ac.id,nandasaputra680@gmail.com
}

\begin{abstract}
:
Talking about the problem of tuk-tuk, we talk about cultural issues, because tuk-tuk has become a culture, especially for the Madurese community. Culture has many meanings, one of which is a way of life that develops and is shared by a group of people, and is passed down from generation to generation. This study aims to see the relationship or correlation between the tuk tuk culture and improving the welfare of the Madurese community. Then the results of this study reveal that the tuk utuk culture can lift the economy of active members of utuk-utuk and the Madurese community of course. With the capital obtained from tuk-tuk, we are able to manage it so that it can develop a bigger business, so that it can increase welfare both individually and as a community.
\end{abstract}

Keywords:

Tuk-Utuk; welfare improvement; Madurese culture

\section{Introduction}

Culture is made up of many complex elements, including religious systems, politics, customs, languages, clothing, buildings, and works of art. Language, like culture, is an inseparable part of human beings, so many people tend to think of it as genetically inherited. When a person tries to communicate with people of different cultures and adapt their differences, it proves that culture is learned. Culture is a comprehensive way of life. Culture is complex, abstract, and broad. Many aspects of culture also determine communicative behavior. These socio-cultural elements are scattered and encompass many human social activities.

Culture is the whole idea and work of humans, which must be familiarized with the learning process, along with the whole of the results of the mind and his work". In essence the culture itself consists of several elements including; language, people belonging to a group, religion, beliefs, and religious system. In accordance with the opinion of Koentjaraningrat in Martozet and Nurwani (2019)

Because the culture is very complex, there are so many cultural understandings written by scientists who study culture, including the following. Culture or culture comes from the Sanskrit language, namely buddhayah, which is the plural form of buddhi (mind or reason) which is defined as matters relating to human mind and reason. In English, culture is called culture, which comes from the Latin word colere, which means to process or work. It can also be interpreted as cultivating land or farming. The word culture is also sometimes translated as "culture" in Indonesian. Culture in Anthropology is often defined as the whole system of ideas, actions, and the results of human work in the context of community life which is made the property of humans through the learning process. 


\section{Lakhomi Journal: Scientific Journal of Culture \\ ISSN: 2774-311X (Online), 2774-4728 (Print)}

Vol. 2, No. 3, September 2021, Page: 101-108

Email: lakhomijournal@gmail.com

From the above definition, it means that almost all human actions are culture. Because, only a few human actions that come from instinct without going through the learning process. For example, the act of eating. Eating is actually a human instinct for survival. However, after inserting culture, there are ways to eat that are cultured, polite, appropriate, or in accordance with aesthetics.

Culture is closely related to society. Melville J. Herskovits and Bronislaw Malinowski argue that everything contained in society is determined by the culture that is owned by the community itself. The term for that opinion is cultural determinism. Herskovits views culture as something that is passed down from one generation to another, which is then referred to as superorganic. According to Andreas Eppink, culture contains the whole notion of social values, social norms, science and all social, religious, and other structures, in addition to all the intellectual and artistic statements that characterize a society. According to Edward Burnett Tylor, culture is a complex whole, which includes knowledge, belief, art, morals, law, customs, and other capabilities acquired by a person as a member of society. According to Selo Soemardjan and Soelaiman Soemardi, culture is a means of the work, taste, and creativity of the community.

From these various definitions, it can be concluded that culture is something that will affect the level of knowledge and includes a system of ideas or ideas contained in the human mind, so that in everyday life, culture is abstract. While the embodiment of culture are objects created by humans as cultural beings, in the form of behaviors and objects that are real, for example behavioral patterns, language, living equipment, social organization, religion, art, and others, which all of which are intended to help humans in carrying out social life. Culture is something that is very complete, which is endless for discussion, because culture is a dynamic thing, not something that is static, as long as humans are still on this earth then culture will continue to develop related to cultural issues.

In practice, the word culture refers to "elite" objects and activities such as wearing classy clothes, fine art, or listening to classical music, while the word cultured is used to describe people who know about, and take part in, activities in the community on. For example, if someone thinks that classical music is music that is "classy", elite, and has an artistic taste, while traditional music is considered as tacky and outdated music, then there is an assumption that he is a "cultured" person.

\section{Review of Literature}

A large culture usually has a sub-culture (or so-called sub-culture), which is a culture that has little difference in behavior and beliefs from the parent culture. The emergence of sub-cultures is caused by several things, including differences in age, race, ethnicity, class, aesthetics, religion, occupation, political views and gender.

There are several ways that people do when dealing with immigrants and cultures that are different from the original culture. The way people choose depends on how much difference between the parent culture and the minority culture, how many immigrants come, the nature of the indigenous people, the effectiveness and intensity of intercultural communication, and the type of government in power. The following are the types in question: 
1. Monoculturalism: The government seeks cultural assimilation so that people of different cultures become one and work together.

2. Leitkultur (core culture): A model developed by Bassam Tibi in Germany. In Leitculture, minority groups can maintain and develop their own culture, without conflicting with the parent culture that exists in the original community.

3. Melting Pot: Immigrant/foreign cultures mingle and merge with indigenous cultures without government intervention.

The theories that exist today assume that (a) culture is a product of the stabilization inherent in the evolutionary pressure towards togetherness and common consciousness in a society, or commonly called tribalism. The culture that is characteristic of most Madurese people, which until now still exist on the island of Madura, which will be explained by the author, starting with the general Madurese culture.

Madura Island consists of four districts, namely Bangkalan, Sampang, Pamekasan and Sumenep, located in the northeast of the island of Java with coordinates about 7 south latitude and between 112 and 114 east longitude. The length of the island of Madura is approximately $190 \mathrm{~km}$, the widest distance is $40 \mathrm{~km}$, and the total area is $5,304 \mathrm{~km}$. The altitude above sea level ranges from 2 meters - 350 meters. The lowest elevations are coastal areas both in the west, north east and south. While the highest altitude spreads in the middle of the island in the form of small mountains. This island is surrounded by more than 100 small islands, both inhabited and uninhabited. Most of these small islands are in the east.

Although Madura only consists of four regencies, judging from the cultural aspects that are adopted and used as standards in behavior, there is no difference between the Madurese people who inhabit the four regencies. Madura is known for its uniqueness and cultural peculiarities. The use of the term typical here refers to the understanding that ethnic Madurese entities have cultural specificities that are not similar to the ethnography of other ethnic communities.

Latief Wiyata said that the specificity of the culture was seen, among others, in their hierarchical obedience, submission and submission to the four main figures in life, especially in the practice of diversity. The four figures are Buppak, Ebuh, Guru ben Rato (father, mother, teacher and leader). It is to these four main figures that the hierarchical obedience of the Madurese manifests itself in their socio-cultural life.

Madura has a lot of traditional wealth, diverse and very valuable. In facing the global world that brings the influence of materialism and pragmatism, the presence of traditional arts in social life in Madura is very necessary, so that we are not trapped in foreign morality that conflicts with local morality or national identity. We as Indonesians must know the Madurese culture that is still alive, even those that will and have become extinct. The introduction of various kinds of Madurese culture will hopefully be able to arouse our national sense of regional arts.

Madura is known as a barren area but rich in culture. The cultural wealth found in Madura is built from various cultural elements, both from the influence of animism, Hinduism and Islam. The marriage of these three elements is very dominant in coloring the existing culture. In its development, various arts with a religious spirit, especially Islamic nuances, turned out to be more prominent. The diversity and various forms of traditional cultural arts in Madura show how high the culture of the Indonesian people. 
Culture that contains noble values based on Islamic religious values should be preserved and introduced to the younger generation as the successor of the nation's heritage. Local culture is a wealth asset that will be able to protect the younger generation from the negative effects of the globalization era. The influence of global culture that is so intense through electronic media and print media causes the younger generation to lose their identity.

\section{Result and Discussion}

One of the cultures or traditions of the Madurese community, especially the Sampang and Bangkalan regencies which is still being preserved is tuk-Utuk. Basically tuk-Utuk dan, the only difference is the form of entertainment served and the number of guests who come. The entertainment presented in remuh is Sandur Madura, which is a typical Madurese art, if in Java a kind of ludruk is enlivened by male dancers who make up like women (tandek). people beleter, and at the core of the event, remoh members are invited to dance with the tandek with the type of dance according to their wishes, an event like this does not exist in the otokotok organization. Meanwhile, in the implementation of tuk-Utuk entertainment, only dangdut and sandur songs are presented through a tape recorder using loudspeakers (speakers and the like). Thus, from a distance it can be distinguished whether it is tuk-Utuk.

Tuk-Utuk is a tradition of carrying out this activity which is carried out during certain events or during walimah for the Madurese community. This tradition is ingrained, in the implementation of walimah whose implementation aims to raise money. And also as a descendant of Madura who is still thick with his tradition even though he is outside Madura, he also carries out the same tradition, namely tuk-Utuk.

Humans are social beings who interact with each other. In social life, the need for such interaction is to establish a harmonious relationship with other individuals. Interaction is a reciprocal relationship and response between individuals, between groups, as well as between individuals and groups. In the Madurese ethnic community, the way to maintain harmony in communication and strengthen ties of brotherhood with other family members is by holding tok-otok / remuh (family gathering). This activity is carried out to get to know other family characters and can strengthen brotherhood ties. Utuk-utuk is a gathering activity consisting of groups of people who collect money regularly in each certain period. Utuk-utu operates outside the formal economy as another system for saving money, but this activity is also intended to be a meeting activity that has a "forced" element because members are required to pay and come every time an invitation is to be carried out. When Utuk-utuk takes place, members can exchange information, share problems in the household, share experiences, agricultural problems and many other things.

In addition to the advantages there are also disadvantages of Utuk-utuk activities. Some individuals use tuk-Utuk as a means of 'showing off the advantages they have. This is what sometimes causes friction between members of Utuk-utuk. The Madurese ethnic community has its own way of maintaining kinship solidarity. Both those who are still living in Madura or those who are wandering outside Madura. The Madurese have a reliable defense. 
Besides the existence of very high solidarity among them, they have one form of vehicle that is able to provide movement and interaction in a planned manner, namely the utuk-utuk tradition. This activity is carried out from generation to generation or generation to generation. This has the meaning of an activity that is carried out from generation to generation and is part of the community.

In the implementation of this activity, it is carried out at night until the early hours of the morning or all night long, but there are also those during the day, starting from 0700 to 20 00. In this activity there are several events, one of which is displaying Madurese arts, in the form of dances. In the Madurese tradition, tuk-Utuk is a big activity. The meaning of the big word here is that tuk-utuk is an activity similar to social gathering with a series of events attended or attended by all ethnic Madurese who are members of the activity. The tuk-utukini event is always accompanied by music, both local and non-local music.

The tuk-Utukini culture is an activity which is a prestigious event among ethnic Madurese. The existence of this activity is to strengthen and maintain the solidarity of ethnic Madurese kinship wherever they fall, because the tuk-utukini activities are also carried out by the Madurese outside Madura, such as in Surabaya. In this case, what is meant by relatives or relatives is people who have "blood relations" with other people (other individuals) both from their mother's and father's descendants. There are many people who are related by blood, so it is very likely that they do not know each other. They only know a few of them and know the intricacies of their kinship with them, because of all their "biological" relatives, only a small part are their "sociological" relatives.

The kinship relationship is determined by the principles of selective descent, binding a number of relatives who together have certain rights and obligations, such as inheritance rights to property, titles, libraries, and others. As well as the right to position, the obligation to carry out activities carried out together and the obligation to carry out productive activities together. This is also done by ethnic Madurese who are overseas residents in Surabaya with the activities they carry out, namely utuk-utuk.

\subsection{Benefits of Tuk-Utuk for Community Welfare}

The term social welfare was first put forward at the World Conference for ministers responsible for social welfare in 1968, when an invitation was issued to development policy makers in developing countries. Also, the term social welfare is not a new discourse, both at the global and national levels.

The increase in per capita income which is quite high in East Java and the shift in the structure of the economy that has taken place so far have not completely eliminated the gap between regions. Especially the Madura island region, its economic growth is always below that of East Java.

Madura Island is rich in natural and cultural products. Many natural products such as agriculture, plantations, fisheries to mining can be found in Madura. Likewise with local culture, such as the bull race, which is one of the regional characteristics that is known internationally. However, the natural and cultural wealth is still not managed properly and optimally. This natural and cultural wealth should be managed and utilized properly to help improve the welfare of the community. In fact, if it can be managed properly, it can be a source of substantial foreign exchange for the State which in essence will help the welfare of the Madurese community. 
The above conditions have prompted the East Java Provincial Government to build the Suramadu bridge that connects Madura with Surabaya. It is hoped that the development of the Madura region will be accelerated due to the expansion of the Surabaya industrial area to Madura. The bridge that connects Surabaya and Madura is expected to be a bridge of change and hope, not only for the Madurese but also for all Indonesians. New changes that are better and more advanced in the sectors of infrastructure development, economy and education now have great hopes for the entire Madurese community along Suramadu.

Social welfare is one of the government programs that never ends / never ends, this social welfare issue has been an interesting topic of discussion since 1968, it has even been regulated in Indonesian law number 6 of 1974 as explained by the author. above which has been quoted from Edi Suharto's book. In Indonesia, the problem of social welfare is a very complex problem, because most of the Indonesian population has a lower middle economic level. So from that the government has not been able to solve this problem.

Meanwhile, the benefits of tuk-Utuk culture on social welfare, such as the findings of researchers in the field, are related to the economic development of several tuk-Utuk members in Gunung Eleh Village, Kedungdung District, Sampang Regency, as Muali has felt as an active member of Utuk-utuk. With the capital obtained from tuk-Utuk, he is able to manage it so that he can now become a distributor agent for building materials such as bricks, sand and so on.

Not only these two people have felt lucky since joining the otok-otok cultural activity, there are still many other members who are lucky by participating in these activities, this can be felt by members if these members can use the money they earn, in the sense of being able to manage well, if it can be done it does not require the possibility that the member will get worse, because he is trapped in a debt that is getting more and more prolonged.

If this is related to the practice that occurs in Islam, this is a form of compassion between fellow humans, because in this case there is an element of mutual assistance as in the practice of refunding money carried out by otok-otok members. As explained by the researcher, the refund must be above the money submitted first. This is then considered a form of help as explained in the Qur'an in the letter Al Maa'idah verse 2 which reads:

Which Means:

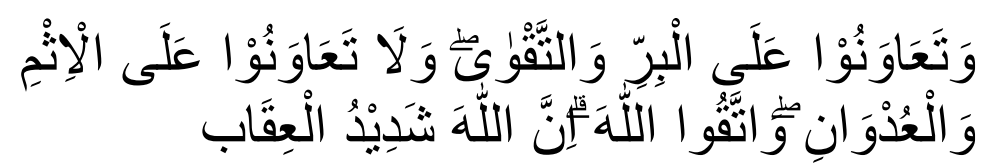

And help you in (doing) righteousness and piety, and do not help in sin and transgression. And fear Allah, verily Allah is severe in punishment.

Community empowerment is a continuous cyclical process. A participatory process in which community members work together in formal and informal groups. To share knowledge and experience as well as efforts to achieve common goals. So community empowerment is more of a process, whether the process is carried out individually or by groups in the community. 
Basically assets are defined by Kretzmann and McKnight as the "gifts, skills and capacities" of "individuals, associations and institutions" cited by Anna Haines in her article Asset-Based Community Development in the book An Introduction to Community Development with editors Rhonda Phillips and Robert H. Pittman.

In an economic context, assets can be forms of capital such as property, stocks and bonds, and cash. In the context of society, assets may be seen as various forms of capital as well. Assets take many forms in society. Ferguson and Dickens (1999) speak of five forms of community capital: physical, human, social, financial, and poly-vertical. Green and Haines (2007) identified seven forms of community capital: physical, human, social, financial-social, environmental, cultural, and political. Rainey et al. (2003) present three forms of capital which they see as important: human, community (physical), and social.

Society cannot be separated from the privileges it has, whether potential or problems are always involved in people's daily lives. One of them is the community assets described above. In this case, assets can be in the form of human resources and natural resources owned by the community. Inside these assets there is social capital that can be developed by the community. From this it can be seen the potential that must be developed by the community to achieve prosperity.

Kretzmann and McKnight identified five characteristics of community-based development assets as follows:

1. Asset based is community or community empowerment that starts with what is in the community or problems in the community. It is focused on customary assets as opposed to perceived needs. Assets are resources that can, and should be used to achieve positive and sustainable change in a community

2. Build internal relationships. Building links between local assets for mutually beneficial issues in the community Mobilizing community assets fully for the economy

3. Building the vision of the congregation as broad as group representatives

4. Establishing external connections

These measures can also be applied to community engagement with technology. Mapping assets can identify community resources relevant to community technology initiatives. This includes assets that could benefit from, or contribute to, initiatives such as the skills and abilities of residents, products and services.

In the storytelling process, certain people will emerge as leaders in the community of people who have demonstrated commitment and leadership in the past or who are currently taking leadership roles. The next step is to organize a group of such committed individuals who are interested in further exploring community assets and acting on identified opportunities. Each individual will have a network of relationships within the community that they can draw into the process. Each individual will have a personal interest - something that motivates him to act. Three things that support prosperity when linked to the tuk-Utuk culture above are: mapping, raising assets and investing from outside the community.

a. Mapping

Mapping is more than collecting data. It is of utmost importance that citizens and their associations conduct their own asset mapping so that they themselves build new relationships, learn more about the contributions and talents of member societies, and identify potential relationships between different assets. 
b. Raising Assets for Community Development

The process continues as the ongoing mobilization of community assets for economic development and information sharing objectives is initiated by the association base. Associations are encouraged to get involved by engaging their interests, discovering common ground and ensuring that they contribute on their own terms

c. Leveraging Activities, Investments and Resources outside of the Community

This is done to support locally defined asset-based development. The process of realizing the community's vision begins with the association asking ourselves what we can do to make it happen. This puts the community in a strong position in dealing with outside agencies.

\section{Conclussion}

From this study it can be concluded that the tuk utuk culture can lift the economy of active members of the utuk-utuk and of course the Madurese community. With the capital obtained from tuk-Utuk, we are able to manage it so that it can develop a bigger business, so that it can increase welfare both individually and as a community. However, if the member cannot take advantage of the money he earns, meaning that he cannot manage it properly, and then it is possible that the member will get worse, because he is in debt that is getting longer and longer.

\section{References}

Adib, Mohammad, (2009). Etnografi Madura, Surabaya: Pustaka Intelektual

Ali, Mahrus. (2009). Menggugat Dominasi Hukum Negara, penyelesaian perkara carok berdasarkan nilai-nilai budaya masyarakat Madura. Mata padi presindo: Yogyakarta,

Haines, Anna. (Tt). "Asset-Based Community Development" dalam Rhonda Phillips and Robert H. Pittman (ed), An Introduction To Community Development

Harsojo (1964) pengantar Antropologi. Bandung: Universitas Negeri Pajajaran

Huraerah, Abu. (Tt) Pengorganisasian Dan Pengembangan Masyarakat, Model Dan Strategi Pembangunan Berbasis Kerakyatan. Bandung: Humaniara

Jonge, De. (1989). Madura dalam empat zaman: pedagang, perkembangan ekonomi dan Islam Studi Antropologi Ekonomi. Jakarta: PT. Gramedia

Martozet and Nurwani. (2019). Sentimental Values in Tor-Tor Parsiarabu in Tomok Toba Samosir Village. Budapest International Research and Critics Institute-Journal (BIRCIJournal). P. 167-171.

Rifai, Mien Ahmad (2007) Manusia Madura: Pembawaan, Perilaku, Etos Kerja, Penampilan, dan Pandangan Hidupnya seperti yang Dicitrakan Peribahasanya. Yogyakarta: Pilar Media

Wahya, Ramdani, (2007) Ilmu Budaya Dasar. Bandung: Pustaka Setia

Wiyata, Latief A., Madura yang patuh?; kajian antropologi mengenai budaya Madura, (FISIP UI, Jakarta,2003) 